\title{
Brain and Acute Leukemia Cytoplasmic Protein
}

National Cancer Institute

\section{Source}

National Cancer Institute. Brain and Acute Leukemia Cytoplasmic Protein. NCI

Thesaurus. Code C103993.

Brain and acute leukemia cytoplasmic protein (180 aa, $19 \mathrm{kDa}$ ) is encoded by the human BAALC gene. This protein may be involved in synapse function or hematopoiesis. 